\title{
NEW INTEGRATION PERIOD? \\ CHANGING TENDENCIES OF THE URBAN NETWORK \\ IN SOUTH EAST EUROPE
}

Szilárd RÁCZ, scientific secretary

Institute for Regional Studies Centre for Economic and Regional Studies Hungarian Academy of Sciences

Address: $\quad$ Papnövelde u. 22. Pécs H-7621

E-mail: $\quad$ szracz@rkk.hu 
Rácz, S.

\title{
NEW INTEGRATION PERIOD? \\ CHANGING TENDENCIES OF THE URBAN NETWORK \\ IN SOUTH EAST EUROPE
}

Keywords: gravity model, trade issues, FTA, Regional Trade Agreements, EU enlargement, panel data

\begin{abstract}
The past two decades have brought basic changes in the whole Balkan Peninsula, where spatial structures and settlement network were not devoid of changes either. Due to the change of the economic, political and social regime and the new borders spatial structures became differentiated along new factors. Cooperation programs of the Euro-Atlantic integration hold many new challenges and opportunities. Historical and political literature studying the single countries' transformation is large and far reaching, however, a settlement network and spatial structure focused overview has been, so far, missing from the range of researches. The aim of this study is to examine the urban features and the spatial transition of the Balkan states.
\end{abstract}

\section{INTRODUCTION - SPATIAL CONCEPTS OF THE BALKANS}

The concept of South East Europe as a separate region appeared in the middle of the $18^{\text {th }}$ century on the maps, however, holding a different spatial content. In 1808 Zeune, a German geographer designated the peninsulas of Europe, including the Balkan Peninsula (Zeune, 1808). The physical geographical designation of the Balkan Peninsula was a problem already for Zeune (Carter, 1977), physical geography has been struggling ever since to make a spatial designation acceptable for most of the academics (Todorova, 2009). There is no consensus on the designation of the Balkan Peninsula, because this peninsula is linked to the main body of the continent with a wide "neck". The neck does not separate the peninsula from the continent; in fact, it opens it up to the Alpine, Carpathian areas. Designation of the Carpathian (Pannonian) Basin has been a similarly difficult task also, partly due to the basin-mountain dichotomy.

The Balkan Peninsula is one of the largest physical geographical regions in Europe, whose northern borders are defined in different ways, Trieste-Odessa line, Sava and Danube Rivers etc. The region is heterogeneous from a physical geographical aspect; all geographical features of Europe appear here. Nevertheless it is not geography from which aspect the region is most complicated. On the peninsula there has always coexisted a complicated mosaic of peoples, cultures, religions etc., therefore the intensity of historical events has always been high in this region. 
In a European macroregional view, several spatial categories appeared in the $20^{\text {th }}$ century besides Southeast Europe, the Balkan Peninsula and the Balkans. With some territorial overlaps but also with different meanings were defined the concepts CarpathianBalkans Europe, Danubian Europe etc., involving considerable territories in the Balkan Peninsula.

The transnational cooperation spaces of the European Union are interesting inasmuch as the development and cooperation relations were formed around and within the Balkan Peninsula. Programming areas are only made for program periods, so they do not influence the long-term development of the structures (Gál, 2009). The program area of the EU strategy for the Danube Region covers a large part of the Peninsula. This may also mean at the level of spatial view that the dominant geographical and political element of the Balkan Peninsula is not the seas around it but the Danube River.

The above-mentioned spatial categories themselves are components of a historically conflict-laden process and the designated areas have specific meanings for almost everyone. Inner acceptance of the specifically defined territories was and still is problematic in most cases. After the regime changes new spatial categories were born. The concept post-socialist covered the major part of the Peninsula excluded Greece and the European part of Turkey. The concept post-Yugoslav includes the countries gaining sovereignty in the territory of the Former Yugoslavia. The Western Balkans already appeared formerly as a topographical category but it is a new formation as a political category created by the European Union in 1998. A decisive element in the birth of this political spatial concept was to differentiate the post-Yugoslavian countries along with Albania from Bulgaria and Romania (Eastern Balkans), the two states that were given an accession chance. Slovenia was considered as part of the Western Balkans, after its EU accession it was only exceptionally mentioned as a country of this spatial category. It became more and more understood that the Western Balkans concept was made for the extra-EU countries. The content of this spatial category has been modified several times since then and presumably it will not last for long.

\section{SYSTEMIC CHANGES IN THE BALKAN PENINSULA}

From the end of the 1980s in Southern and Eastern Europe the unfolding processes may also be considered colourful. An ethnic element appeared, stated or not. The Balkan Peninsula both at the time of Cold War Era and at the time of the later co-existence of the 
bipolar world represented the whole of Europe in miniature. Prior to the radical transition in 1990, the Socialist and Western state systems existed over a relatively small territory. As well as the conservatively communist Bulgaria, the presence of non-aligned Yugoslavia, and the nationally communist Albania, there were two NATO members (Greece, Turkey), one of which was a European Community member (Greece). Systemic changes of the socialist states of the Balkan Peninsula are in line with the major tendencies. Rearrangements between 1989 and 1991 took place in at least three different ways: negotiations; smaller or greater opposition, social conflicts; and finally in tragic civil war (Anderson, 1995; Hadži-Jovančić, 1995; Johnsen, 1995; Melčić, 2007; Nikic, 1994; Woodward, 1995).

Countries of the Balkan Peninsula experienced historical development processes that were similar in several aspects, but also very complicated and very much different and in some other ways. By the end of the cold war period it was rather heterogeneity than homogeneity that became a typical development characteristic and result in the countries of the Balkans. The respective countries of the region arrived at the starting line of the "new world order" with a variety of historical heritages and specific economic, social and political experience. The large-scale rearrangement of national territories taking place in this region was thus not a "Balkan feature", not a peculiar and unique phenomenon in this period, but in civil war circumstances it did possess had individual and unique characteristics (Hajdú-Rácz, 2011). The social, economic and political systemic changes occurring in the Balkan Peninsula necessarily and fundamentally concerned the issue of Yugoslavia and related to Yugoslavia and almost all neighbouring countries in some way. The crisis of Yugoslavia, a country with large territory and population, a country that was actually a regional power with a leading role among the non-aligned countries, generated spillover effects (Hajdú, 2010, Jovic, 2001, Trbovich, 2008).

There were also considerable differences across the respective states as regards whether radical transformation took place within the "old national frameworks" (Albania, Bulgaria, Romania), whether new states were born. In the newly created states (which make up the majority in the region in question) the issues coming from the disintegration of the old state structures and the problems of the new arrangements of the state had to be handled simultaneously. During the state formation, new nation and state concepts were made, new capital cities were designated and the relation of the new elites to the territory of the state also changed. 
In the Yugoslav area, systemic change coincided with the strengthening of nationalism, as both the old and the new political elite expected to find their "real" roots in this nationalism, which became a political "calling" for a while. The need for handling the issue of multi-ethnicity arose during the working out of the new constitutional arrangement and also with the creation of the administrative systems and spatial divisions. The new state majorities were usually unwilling to offer territorial autonomy to ethnic minority areas. The approach to the ethnic minority areas has become a significant and peculiar issue of decentralisation and regionalisation (Hajdú, 2010).

The collapse of SFRY and the formation of the new states affected not only the citizens of former Yugoslavia, but also all the states on the Balkan Peninsula. It is no accident that Greece had serious concerns over the establishment of the Republic of Macedonia, since it saw the latter's mere existence as a historical, political and national security threat. The breakup of SFRY also fundamentally affected Albanians living in former Yugoslavia and Albania. It was evident that with the collapse of SFRY, in some Yugoslav successor states the significance of the proportion of Albanian inhabitants and their economic and political importance would grow. The Albanian settlement area - in part in its homogenous coverage - embraced a number of national border regions, especially in Macedonia, Serbia but in also Greece (Hajdú-Rácz, 2011).

New state borders were erected in place of the old internal administrative borders. Some of the new state borders turned into closed ones, practically giving the appearance of classical military borders. International borders and crossing facilities divided special state units in the former unitary political geographical space. The second question within the "separation process" was: "Who has the right to self-determination?" Within the complicated political situations (between 1991-1995, and in 2008) the ambition manifested itself that the "peoples", the "nations", the republics, "the majority settlement areas" all had a right to and opportunity for self-determination. Others considered that such ambitions only related to those areas which had previously also had their own constitutional mandate (republic level).

\section{DEVELOPMENT OF THE URBAN NETWORK}

The past two decades have brought basic changes in the whole Balkan Peninsula, especially on the territory of the former Yugoslavia, where spatial structures and settlement network were not devoid of changes either (Petrakos-Economou, 2002; Dimou-Schaffar, 
2009). War destruction (Coward, 2004; Graham, 2004; Riedelmayer, 2002; Nation, 2003) affected the transformation of regions and towns just like changes of demographical, migration and ethnic circumstances (Hammel, 1993; Ramet, 2005, 2006; Đurđev et al., 2009). Due to the change of the economic, political and social regime and the new borders spatial structures became differentiated along new factors (Koči-Pavlaković-Pejnović, 2005; Zeković, 2009). Cooperation programs of the Euro-Atlantic integration hold many new challenges and opportunities (BBR 2006; ÖIR 2006; RePUS 2007; Papadaskalopoulos-Karaganis-Christofakis, 2005; Hardi, 2012).

To be able to understand the present town network and feature potential development directions we need to get acquainted with its genesis. Three main factor groups have influenced the formation of the town system: physical geographical conditions, prevalent changes of state borders and ethnical-cultural divergences.

Figure 1 Urban network of the Balkans, 2011

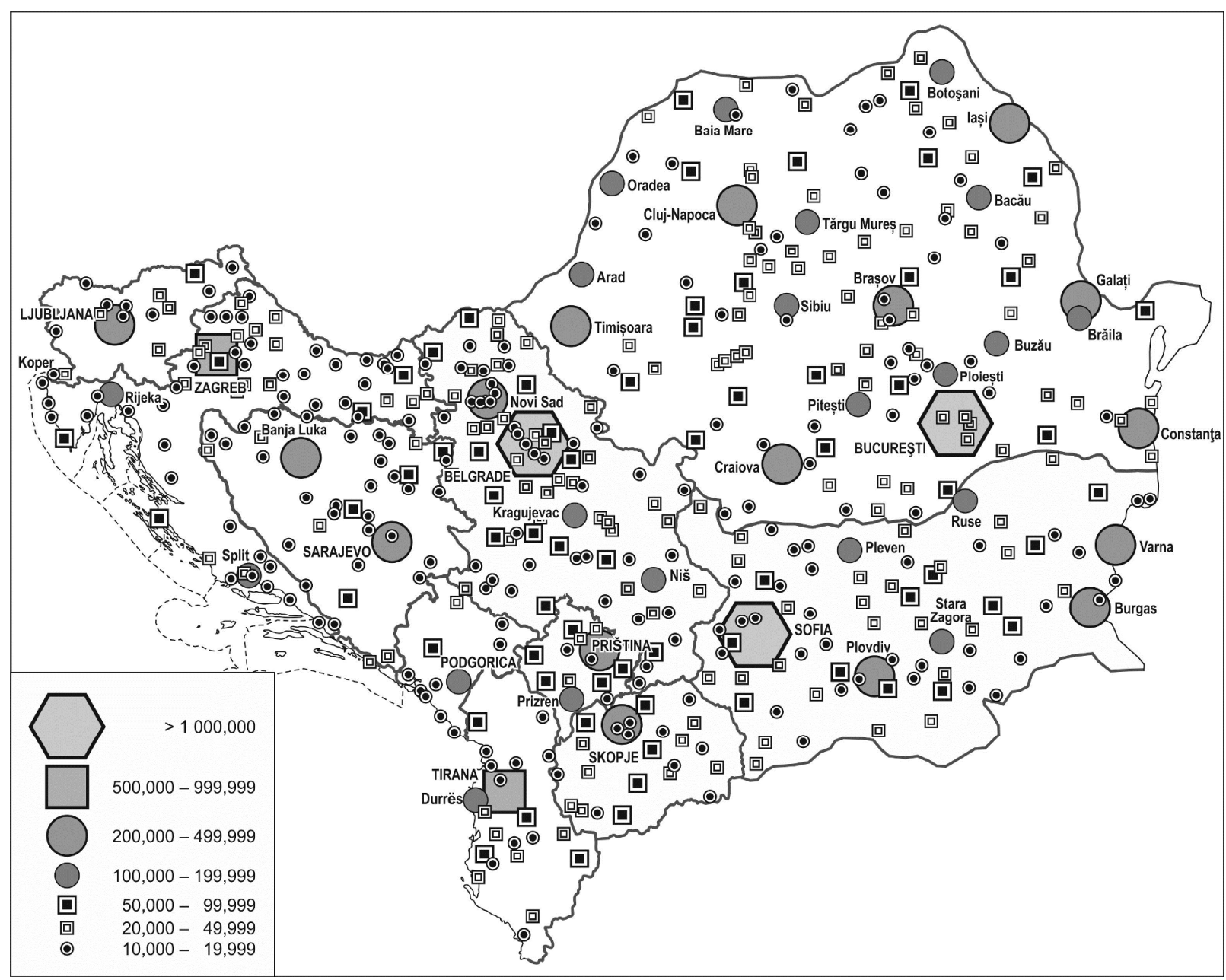

Source: Author's own construction based on census and statistical yearbook dates. 
Natural features have facilitated, or in other cases blocked, inter-settlement interaction. The Dinaric Alps hampers links between the coast and the northern territories, whilst the Adriatic has almost pre-ordained relationships among the coastal settlements and maritime trade. Mountain valleys, safe harbours along the coast are, necessarily, meeting points of socio-economic relationships, and this meant advantageous local conditions for town development. However, those coastal settlements, which were located on a road or on a railway saw their networks maintain their good development potential. Among the towns on the mainland located in valleys, it was mainly those situated at the junction of several roads which were able to maintain their positions over time. The Danube and its tributaries, as well as the roads running parallel with these, had facilitated the formation of towns. Securing access to the sea and the development of a national port was a crucial consideration in the new Yugoslavian states.

The Balkans has been a periphery throughout the centuries; it has never been in the developmental centre of a major region. The ever-changing political structure is a special feature of the city network. Once there were independent countries, whilst at other times the territory formed part of a major empire. Political instability led to rapid demographic, economic and administrative changes, and the urban network was constantly forced to adapt to these, whilst the settlements had to adjust their own functions to their changing roles. From these constant changes, it follows that not even one town in the Balkans area had the opportunity for uninterrupted development: there was no dominant city formed and the actors changed - even at the different levels of the urban hierarchy.

Changes of regime, the influence of other cultures, as well as their diverse usage of space impacted on towns and their relationships in different ways. As is widely known, the Balkans' ethnic and regional composition is very diverse; its level of multiculturalism is unique in Europe. Different types of towns were formed in the different cultural zones of the Balkans.

\section{URBANIZATION AND CITY GROWTH IN THE BALKANS}

Urbanization was late on the Balkans and it has leeway even in comparison with Central Europe, the Balkan's town network was less dense. Urbanization level of the Western Balkans is still under the European average; it is related to the general underdevelopment based on historic reasons. The fact, that no such city was formed, that could have had durable and significant influence on the whole region is another specificity of the region. 
Socialist industrialization, establishment of new factories and other projects linked to these accelerated migration. Population growth and change of the settlements' character were followed by the change of administrative classifications.

The development of Belgrade, the capital, was not disproportionate in multi-ethnic Yugoslavia. The centres of other regions (Zagreb, Ljubljana etc.) were also developing, and so the urban network was relatively in proportion. Every part of the country or region had its own centre. This was true of both the proportion of small, medium and large towns as well as for the network's geographical location. Belgrade's growth declined by virtue of the fact that the country's government was decentralised in several respects.

Migration stopped in the $90 \mathrm{~s}$, and in some places, its direction changed as well. Industrial jobs disappeared and so many who had found themselves in a hostile ethnic environment moved back to their former homes which ensured both ethnic security and a livelihood. Not only was internal migration significant, but many town-dwellers left the area and moved abroad.

In spite of perpetual urbanization Yugoslavia was lagging behind the European average urbanization level even before its breakup, and its different parts, later on, the different member states were urbanized on very different levels. The Yugoslav wars meant a breaking point for several towns. Towns were devastated and abandoned; a significant ethnical migration took place (Lukic et al. 2012). Urbanization did not keep its former pace of growth in the successor states; a few new town statuses were granted based on administrative concerns, mainly because the former centres got to other states.

After the break-up of Yugoslavia, the new countries aimed principally at strengthening their integrated state territory and establishing their own administration. This meant the development of national capital cities and new administrative centres. The population growth in the capitals changed the formal ethnic proportions, that of the majority nation being increased. Political change had also changed the status of several settlements in the settlement network.

The recently created nation states consider developing their capital cities and town network as a top priority. These efforts are banned by several problems. Natural population growth is low in towns (except the Albanian cities), and so any increase can only result from migration. It is difficult to trace migration, since many consider the move as temporary and do not register at their new domicile. Ethnic conflict produced ethnic segregation in many multi-ethnic towns. Beside ethnic segregation, property-based segregation has also increased. 
Urban network of the Western Balkans might take a new direction in the light of European integration. Towns, regions of bigger cities and coastal settlements having more attractive features are the target for migration. The development of state and administrative functions can be expected in the new administrative capitals; this induces further development. There are ethnic centres, which play a significant role in the ethnicity based development policy.

\section{ROLE OF CAPITAL CITIES AND THEIR REGIONS}

The economic and political changes opened new possibilities for the post-socialist states. The region has a very dynamic period in the last two decades, which continue today. In these countries foreign direct investment was unknown before. In these years, investors discovered these countries as profitable fields of investment (Illés, 2002; Lux-Mezei, 2012). Not all counties were simultaneously discovered. It was, however general that the foreigners invested first in capital cities, in ports and in regions bordering EU member states (Rácz, 2011). It means that investments were concentrated in a few cities and regions, most regions remained without FDI for several years, in many cases until now (Gál-Sass, 2009). Consequently, economic growth also concentrated to capital regions (Hardi-Hajdú-Mezei, 2009). In some cases, the capital city region was the only carrier of economic growth. This result can be interpreted also in a wider context. In the period 1995-2000, peripheral countries and especially the capital cities of peripheral countries grew more rapidly than other regions and cities of the EU.

With the global financial and economic crisis somewhat changed this trend but the long term trends did not changed, regional disparities are showing an increase between centres and peripheries. Capital city regions have lower unemployment; the decrease of the growth rate is less than in the other regions. The main driving force of economic growth continues to be the service sector which is concentrated in the capital cities (Faragó-Rácz, 2011). At the same time, however, national and EU policies have a strong influence on the territorial development of countries, cities and regions. The unambiguous winners of the process are capital regions, exploiting their role as metropolitan growth areas. All of these regions have improved their relative positions, some substantially (Bucurest-Ilfov) while a decline in relative development level has taken place in a number of non-central regions (Lux. 2011). No region outside capital regions has experienced a significant improvement in development ranking (Hajdú-Rácz, 2011). This process highlights the heavily 
metropolitan character of high-technology manufacturing and knowledge-intensive hightechnology services, as well as the functions of economic, financial and political control, where the higher tiers of the globally organised urban network predominate, and the competitive positions of functional urban areas lacking a critical mass are much less advantageous. The concentration of advanced business services corresponds to the urban network: it exceeds $50 \%$ in the capital regions of Slovenia, Bulgaria and Croatia, is below $40 \%$ in Romania, where a more polycentric urban network is present (Erdösi et al., 2013).

It is a general phenomenon in the Balkan states that the vast majority of economic activities are concentrated in the capital cities; they are services, finance, banking, trading, research, higher education etc. in large part. The capital cities are by far the most important centres of transport; the other cities are much more difficult and more slowly can be accessed by means of transport. There are determinant differences between the capital city and the second largest city.

Table 1 Share of capital regions (in percentage of the country)

\begin{tabular}{|c|c|c|c|c|c|c|c|}
\hline & Bulgaria & Croatia & Macedonia & Montenegro & Romania & Serbia & Slovenia \\
\hline Population & 18 & 18 & 30 & 23 & 11 & 22 & 25 \\
\hline $\begin{array}{l}\text { Employed } \\
\text { persons }\end{array}$ & 33 & 19 & 34 & 33 & 12 & 31 & 36 \\
\hline GDP & 36 & 31 & 48 & N/A & 21 & 35 & 36 \\
\hline $\begin{array}{l}\text { Students in } \\
\text { higher } \\
\text { education }\end{array}$ & 47 & 53 & 37 & 67 & 35 & 52 & 60 \\
\hline
\end{tabular}

Source: Author's own construction based on last dates of statistical yearbooks.

\section{SPATIAL DEVELOPMENT OF THE BALKANS IN THE CONTEXT OF THE}

\section{DANUBE REGION}

The region is gradually being integrated into the European Economic Area. The eastern enlargement of the European Union and the fact that, since the re-unification of Germany, the European urban core area has been shifted eastwards does benefit the Danube Region. At the same time, due to the quickening pace of (belated) modernisation, the circle of areas 
and settlements which are starting to fall behind is growing, with certain rural areas facing a loss of functions, the outward migration of their population and general impoverishment.

The urban system of South East Europe will, most likely, be characterised by a number of specific features during the coming decades:

- a polycentric macroregional urban system constituted by monocentric national urban systems and a fragmented rural network,

- a high level of industrial employment in cities compared with European core regions,

- a high concentration of companies of international and national importance in capital cities,

- the weakness of the urban burgeoisie and civil society,

- an increase in poverty and in degenerating social strata,

- the poor condition of the built heritage and the slow disappearance of infrastructural weaknesses.

The individual countries in the area have mainly followed a similar path in their postsocialist transformation, with the objective of 'returning' to Western Europe - implying a strengthening of Western influence and increasing vulnerability. The common past, together with the challenges of the present, outline a form of East Central European development path in which West European urbanisation trends emerge in specific ways. Even in Western Europe as it serves as a role model, the context has become one of increasing uncertainties. The economic driving forces of urbanisation have also been transformed and so the reference point is constantly changing.

The influence of the Danube on the urban network and on spatial development was not only felt in the past but has continued until the present era. Commercial-industrial activities related to the river have contributed to a strong concentration of population on the upper and middle sections of the Danube, and several connection points have been created at the intersection of lines of force on the river, giving birth to a dominant urban Central European zone. From the standpoint of the urban network, the middle section of the Danube has become a true axis of urbanisation (Linz-Vienna-Bratislava-Budapest), which has now extended to the South-East - towards Novi Sad and Belgrade. The lower section of the river is more sparsely populated and rural in nature. Here the Danube long constituted the border to an empire, and, consequently, its territory has remained a periphery. Socialist urban development was also unable to foster any significant changes here, due to the weakness of cross-national connections on one hand, and the fact that the population and 
the economy were traditionally concentrated in ports on the Lower Danube. This is graphically shown by a development slope to be observed along the length of the river. The varying levels of development of the individual sectors will also generate different demands in development terms in the future, and the greatest, the most significant effective of these may occur precisely in the more backward territory of the Lower Danube.

In terms of the rate of urbanisation, a North-West to South-East slope can also be discerned, even if socialist development and the fever to gain 'city' status significantly reduced the existing disparities. In reality, the urbanisation of towns or small cities was far from effective, and in several cases the settlements acquiring 'city' status lacked serious urban functions.

Figure 2 Spatial structure and urban hierarchy of the Western Balkans

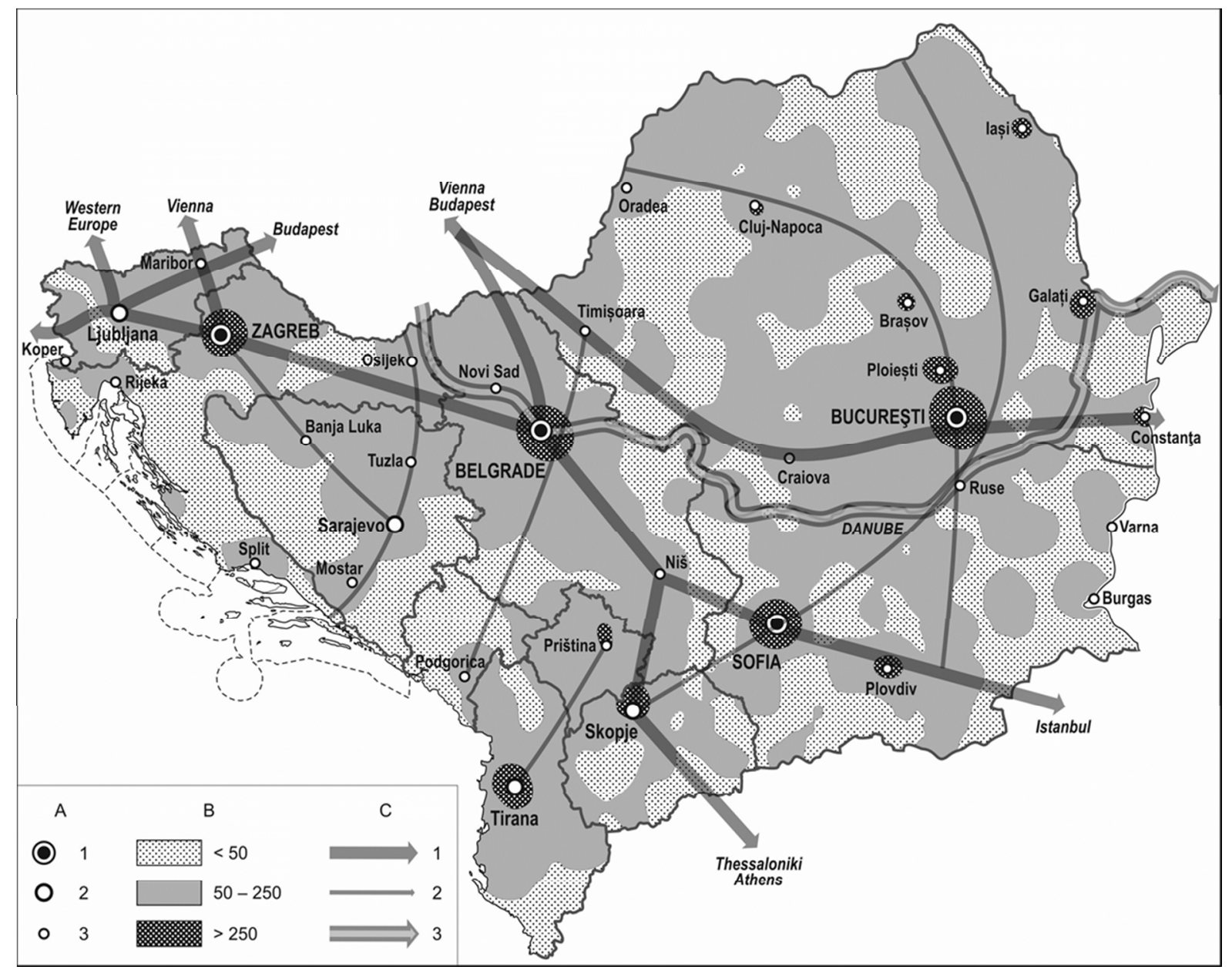

Key: A.1. - World cities, A.2. - Cities, A.3. - Significant urban centres; B -

Population density inh. $/ \mathrm{km}^{2}$.; C.1. - Trans-Balkan routes, C.2. - Intra-Balkan spatial lines, C.3. - Danube

Source: Author's own construction. 
A unified treatment of the region and its development based on coherent strategy is further rendered difficult by the fact that the area has never functioned in the form of a single state, and so its urban network has never constituted a unified system, even when numerous similarities have been visible. The entire area is unquestionably gravitating towards the North-West. None of the major cities of the Danube Region constitutes a dominant core region around which could potentially be organised the entire Danube Region which transcends political and national boundaries. There is no internal centre of gravity which could integrate the region from most aspects. The peak of the settlement network of the area is constituted by cities and city regions with 1-2 million inhabitants (Bucharest, Budapest, Vienna, Belgrade, Sofia etc.). This produces a polycentric urban network in the entire region which will predetermine the future division of functions. A significant outcome of the EU Strategy for the Danube Region would be if the possible functions could be divided among the centres, so enabling the strengthening of network cooperation. The wars in the Former Yugoslavia in the '90s drove a wedge splitting NorthwestSoutheast relations in the region. Due to the enlargement of the EU, an increasing part of the region forms a unified political and integrating economic entity, and so political obstacles to cooperation are being removed.

With the deepening of European integration, the permeability of borders and the intensification of cross-border relations, the outlines of a unified city region and growth district are emerging in the Central Danube Basin. The dynamically developing core region is organised around the Vienna, Bratislava and Budapest axis. The question of whether the area is an enlargement of the European Pentagon or the centre of a totally new Central European growth region is as yet unclear.

\section{CONCLUSIONS}

The Balkan Peninsula is one of the largest physical geographical regions in Europe, whose northern borders are defined in different ways. The region is heterogeneous from a physical geographical aspect; all geographical features of Europe appear here. Nevertheless it is not geography from which aspect the region is most complicated. On the peninsula there has always coexisted a complicated mosaic of peoples, cultures, religions etc., therefore the intensity of historical events has always been high in this region. The different spatial categories (Balkans, Western Balkans, Southeast Europe etc.) themselves are components of a historically conflict-laden process and the designated areas have 
specific meanings for almost everyone. Inner acceptance of the specifically defined territories was and still is problematic in most cases.

One of the most significant characteristics of the urban network of the Danube Region is that the capital cities (excluding Bosnia-Herzegovina with its special status) concentrate the heart of the economy and of the population not only within national borders, but also compared to the second level of the urban network (the regional centres).

We can discern the strengthening of the integrated state territory and autonomous urban networks in those states which have won sovereignty during the past two decades. The development of the new capital cities is most remarkable in the newly established states from every perspective. Macro regional centres are relatively weak, or cannot even be counted as real counterpoles, due to the small size of the countries and the scarcity of resources which have permitted only one metropolis to emerge. Former catchment areas have been transformed with the internationalisation of borders, and so the number of cities providing regional functions has increased (with the new centre-integrating areas losing their former centres). The newly implemented public administrative systems have extended the functions of several settlements. Due to ethnically-based institutional development (e.g. the establishment of universities for minorities) certain cities have gained a senior position in the network independent of any system of public administration.

The phenomenon of suburbanisation can be seen in the region only since the 1990s, but the growth of metropolitan agglomerations has been constant despite the radical decline in birth rates. In parallel, the negative impacts of the process can also be observed (segregation, overburdening of the environment etc.). The losers in the process of migration were rural areas and industrial cities which lost their ability to retain their population. One distinctive movement of population arose due to the wars in the Former Yugoslavia which brought a change in the population numbers and ethnic composition of the settlements involved.

The Balkans region constitutes the most complex periphery of Europe from several perspectives. The cyclical change of integration and disintegration is the major factor shaping territorial and settlement processes. Currently we are witnessing a most advanced stage of disintegration, with the settlement network having reached its most highly fragmented level. Structural transformation has continued until today. Unresolved questions (border problems, unsettled conflicts etc.) make the fulfilment of the new integration cycle very difficult. With the exception of Slovenia every state is running certain risks - for example in terms of ethnic or life quality issues. The urban network of 
the area is currently a system of monocentric (capital-city centred) clusters separated on a national (ethnic) basis.

Certain processes (e.g. national sovereignty, mass emigration, the loss of population from rural areas) would have emerged without the intervention of war, albeit at a much slower pace and to a more moderate degree. With the collapse of Yugoslavia the internal relations of the area were radically transformed. The war and the building of nation states resulted in the termination or the deliberate neglect of former relations. Cross-border cooperation has intensified in certain, mainly ethnic respects, but outside the borders of the region Great Power relations have gained significance, showing varying orientations from nation to nation.

With the end of conflicts and the drawing of new, long-term paths a new era of integration seems to be about to commence. Individual countries do not merely participate as partners, but the competition for attracting foreign capital will become more intensive at both national and settlement level. Integration into the global and European blood-stream can be achieved successfully only by certain countries and a very few cities. For the rest, this remains only a remote possibility. A transition similar to that of the Visegrád Countries is likely to occur: modernisation (integration) will be fulfilled in a top-down direction ar points within the settlement hierarchy, and along European corridors in a North West-South East direction. Hence, capital cities with their established connections will become the primary beneficiaries, further increasing their relative weight. Among the winners in the process will be gateway cities and large cities in general. Among the losers will be settlements and areas 'squeezed' along ethnic borders and facing a peripheral situation due to the change of orientation. The new (urban) network relations will not necessarily rely on former structures, since Europe's interests and scales differ totally from what they were during the Yugoslav era.

\section{LITERATURE}

Anderson, D. (1995). The Collapse of Yugoslavia: Background and Summary. Department of the Parlamentary Library, Canberra. Research Paper No. 14.

BBR (2006). Outlining Central and South East Europe. Report on spatial development in CenSE. Bonn, Federal Office for Building and Regional Planning.

Carter, F. W. (1977). Introduction to the Balkan Scene. In: Carter, F. W. (ed.): An Historical Geography of the Balkans. New York, Academic Press. 1-24.

Coward, M. (2004). Urbicide in Bosnia. In: Graham S. (ed.): Cities, war and terrorism towards an urban geopolitics. Oxford, Blackwell. 154-171. 
Dimou, M., Schaffar, A. (2009). Urban hierarchies and city growth in the Balkans. Urban Studies. 13. 2891-2906.

Dubarle, P., Mezei, C., Pámer, Z. (2011). Regional development programmes. In: Horváth, Gy. - Hajdú, Z. (eds.): Regional Transformation Processes in the Western Balkan Countries. Pécs, Centre for Regional Studies of HAS. 570-601.

Đurđev, B. S., Bubalo-Živković, M. - Ivkov-Džigurski, A. - Ivanović, L. (2009). Majorities and minorities in former Yugoslav countries at turn of the 21st century. Geographica Pannonica. 4. 118-126.

Erdősi, F., Faragó, L., Gál, Z., Grünhut, Z., Hajdú, Z., Lux, G., Illés, I., Kovács, D., Nagy, I., Póla, P., Varjú, V., Rácz, Sz. (2013). Danube Region: Analysis and Long-Term Development Trends of the Macro-Region. Pécs, Institute of Regional Studies CERS HAS.

Faragó, L., Rácz, Sz. (2011). Urban network. In: Horváth, Gy. - Hajdú, Z. (eds.): Regional Transformation Processes in the Western Balkan Countries. Pécs, Centre for Regional Studies of HAS. 256-288.

Gál, Z., Sass, M. (2009). Emerging New Locations of Business Services: Offshoring in Central and Eastern Europe. Regions Magazine. 1. 18-22.

Gál, Z. (2009). The Danube region - past, present and future prospect of transnational cooperation as a playground of the European integration. Eurolimes. Journal of the Institute for Euroregional Studies. 7. 148-158.

Graham, S. (2004). Constructing urbicide by bulldozer in the Occupied Territories. In Graham S. (ed.): Cities, war and terrorism towards an urban geopolitics. Blackwell, Oxford, 192-213.

Hadži-Jovančić, D. (ed.) (1995). The Serbian Question in the Balkans. University of Belgrad Faculty of Geography, Belgrad.

Hajdú, Z., Rácz, Sz. (2011). Urbanisation, state formation processes and new capital cities in the Western Balkans. AUPO Geographica. 2. 63-77.

Hajdú, Z. (2010). State formation processes in the post-Yugoslav space. In: Mladenov Ch. - Nikolova M. - Vatseva R. - Koulov B. - Kopralev I. - Varbanov M. - Ilieva M. (eds.): International Conference Geography and Regional Development: Proceedings. Sofia. 176-182.

Hammel, E. A. (1993). Demography and the origins of the Yugoslav civil war. Anthropology Today. 1. 4-9.

Hardi, T., Hajdú, Z., Mezei, I. (2009). Határok és városok a Kárpát-medencében [Borders and cities in the Carpathian Basin]. Győr-Pécs, MTA Regionális Kutatások Központja.

Hardi, T. (2012). Duna Stratégia és területi fejlödés [Danube strategy and territorial development]. Budapest, Akadémiai Kiadó.

Illés, I. (2002). Közép-és Délkelet-Európa az ezredfordulón. Átalakulás, integráció, régiók [Central and South Eastern Europe at the turn of the Millenium. Transformation, integration and regions]. Budapest-Pécs, Dialóg Campus Kiadó.

Johnsen, W. T. (1995). Deciphering the Balkan Enigma: using History to inform Policy. Strategic Studies Institute, U.S Army War College, Washington.

Jovic, D. (2001). The disintegration of Yugoslavia. A critical review of explanatory approaches. European Journal of Social Theory. 4. 101-120.

Koči-Pavlaković, V., Pejnović, D. (2005). Polarization of Regional Economic Development in Croatia - Trends and Challenges in a New Geographic Reality. Hrvatski Geografski Glasnik. 2. 5-19. 
Lukic, T., Stojsavljevic, R., Durdev, B., Nagy, I., Dercan, B. (2012). Depopulation in the Western Balkan countries. European Journal of Geography 2. 6-23.

Lux G. - Mezei C. (2012). A gazdaságfejlődés szerkezeti és területi problémái a NyugatBalkánon [Structural and Regional Problems of Economic Development in the Western Balkans]. Magyar Tudomány. 4. 407-416.

Lux, G. (2011). The disintegration and reorganisation of industry in the Western Balkans. In: Horváth, Gy. - Hajdú, Z. (eds.): Regional Transformation Processes in the Western Balkan Countries. Pécs, Centre for Regional Studies of HAS. 379-399.

Melčić, D. (ed.) (2007). Der Jugoslawien Krieg. (Handbuch zu Vorgeschichte, Verlauf und Konsequenzen) 2. aktualisierte und erweiterte Auflage. VS Verlag für Socialwissenschaften, Wiesbaden.

Nagy, I. (2007). Szerbia társadalmi-gazdasági helyzete [Socio-economic situation of Serbia] In: Nagy, I. (ed.): Vajdaság. Pécs-Budapest, MTA Regionális Kutatások Központja - Dialóg Campus Kiadó. 29-75.

Nation, R. C. (2003). War in the Balkans 1991-2002. Strategic Studies Institute, U.S. Army War College, Carlisle.

Nikic, G. (ed.) (1994). Croatia Between Aggression and Peace. Zagreb, AGM.

ÖIR (2006). Metropolitan Networking in CenSE backed by North-South Rail Corridors. Final Report of the Pilot Projects. Wien, Österreichisches Institut für Raumplanung.

Papadaskalopoulos, A. - Karaganis, A. - Christofakis, M. (2005). The spatial impact of EU Pan-European transport axes: City clusters formation in the Balkan area developmental perspectives. Transport Policy. 6. 488-499.

Petrakos, G., Economou, D. (2002). The spatial aspects of development in South-eastern Europe. Spatium. 8. 1-13.

Rácz, Sz. (2011). Regions and towns in the contact zone of the Balkans and the Carpathian basin. In: Halasi-Kun, G. J. (ed.): Environmental Protection of Central Europe and USA. Pécs-Bratislava, Slovak Academy of Sciences Institute of Hidrology Hungarian Academy of Sciences Centre for Regional Studies Transdanubian Research Institute. 150-172. (Columbia University, University Seminars).

Ramet, S. P. (2005). Thinking about Yugoslavia: Scholarly debates about the Yugoslav breakup and the wars in Bosnia and Kosovo. Cambridge, Cambridge University Press.

Ramet, S. P. (2006). The three Yugoslavias: State-building and legitimation, 1918-2005. Washington D.C., Woodrow Wilson Center Press.

RePUS (2007). Regional Polycentric Urban System - Strategy for a regional Polycentric Urban System in Central-Eastern Europe Economic Integration Zone. Final report.

Riedlmayer, A. J. (2002). Destruction of cultural heritage in Bosnia-Herzegovina, 19921996. A post-war survey of selected municipalities. Cambridge, MA, USA.

Todorova, M. (2009). Imagining the Balkans. Updated edition. New York, Oxford University Press.

Trbovich, A. S. (2008). A Legal Geography of Yugoslavia's Disintegration. Oxford, Oxford University Press.

Woodward, S. L. (1995). Balkan Tragedy. Chaos and dissolution after the Cold War. Washington D.C., The Brookings Institute.

Zeković, S. (2009). Regional competitiveness and territorial industrial development in Serbia. Spatium. 21. 27-38. 
Rácz, S.

Zeune, A. (1808). Gea. Versuch einer wissenschaftlichen Erdbeschreibung. Berlin, Wittich. 